\title{
Forming a Paradigm of Prophetic Law from the Perspective of Arkanul Bai'ah
}

\author{
Romi Saputra \\ Universitas Muhammadiyah Sumatera Barat, Padang \\ romisaputra87@gmail.com
}

DOI: dx.doi.org10.23917/jtl.v3i1.15224

Submission
Track:
Received:
21 July 2021
Final Revision:
29 September 2021
Available online:
30 September 2021
Corresponding
Author:
Romi Saputra
romisaputra87@gmail
.com

\section{ABSTRACT}

The rational paradigm has long dominated the thinking of mankind in law, not to mention Indonesian legal experts and jurists. By basing a truth on the ratio, the rational paradigm assumes that reason is the only means to arrive at the goals and objectives in law. So it is not surprising that the rational paradigm brings out secularism, pluralism, liberalism, and even to atheism, because with the spirit of ratio it tries to penetrate the walls of sacredness (something that is fixed, holy, and permanent) in religion under the pretext of being critical. Therefore, a new paradigm is needed to balance this rational paradigm by developing a prophetic or transcendental paradigm. The prophetic/transcendental thought has also been developed by Kuntowijoyo, and his studies have been expanded by Indonesian scientists such as Prof. Abosori and Dr. Kelik Wardiono from Universitas Muhammadiyah Surakarta The prophetic paradigm as a new paradigm is still very possible to be studied and explored, so in this paper we will try to build a prophetic paradigm from the perspective of Arkanul Bai'ah which was initiated by Imam Hasan Al Bana as a charismatic ulema and recognized by the world for his knowledge. The problem in this paper is what is the form of the paradigm of prophetic law from the perspective of Arkanul Bai'ah? The research method used of research is descriptive analytical qualitative research, the approach used is a conceptual approach, while the data collection techniques come from the literature or this research is also called library research. The results of this study: ontology of prophetic law from the perspective of Arkanul $B a$ 'iah is that the meaning of the law refers to the substance of Allah SWT (Allah Himself), so in understanding legal issues, it is obligatory to be guided by the Qur'an and Sunnah and use them as a benchmark in weighing the truth. Epistemologically, prophetic law views science and revelation as a unity that cannot be separated (integrated), when there is a conflict between revelation and reason, revelation must take precedence. Then in scientific development, it is necessary to pay attention to the framework that is tsawabit and mutaghayirat so that shari'ah and 
reason work according to the designation of their respective territories. And axiologically, prophetic law is useful in presenting benefit, justice, grace and wisdom.

Keyword: Paradigm, Prophetic Law, arkanul bai'ah

\section{INTRODUCTION}

The rational paradigm as a paradigm that is quite old in the science of law has long mehegemonized the world of legal thought. This is evidenced in almost every country that upholds the rule of law, basing its legal thinking on legal positivism.

In contemporary law, positivism according to Prof. Herbert Lionel Adolphus Hart, distinguishes five meanings of "positivism" namely: (1) the assumption that laws are commands of human beings; (2) the assumption that there is no need for a relation between law and morals or existing laws and laws that should exist; (3) the assumption that the analysis (study of the meaning) of legal conceptions: a. worth continuing, and b. must be distinguished from historical research on the causes or origins of law from sociological research on the relationship of law to other social phenomena, and criticism or appreciation of law whether in the sense of morals, social demands, functions, or otherwise; (4) the assumption that the legal system is a "closed logical system" where appropriate legal decisions can be produced in a logical manner from predetermined legal rules without considering social demands, wisdom, moral norms, (5) the assumption that moral judgments cannot be given or defended. For example, Statements about facts, with rational reasons, clues, or evidence (non-cognitivism in ethics) (Sudiyana \& Suswoto, 2018). The rational paradigm not only tries to separate law and morals, also considers written law to be the actual law, but also what is even worse is the appearance of secularism, liberalism, and pluralism in responding to legal issues. Of course it has a very clear reason as the positivistic theory put forward by Auguscomte which ignores metaphysical problems.

For this reason, the presence of a new paradigm is required to balance this rational thought, especially this paradigm is of course very much needed for the state and society which bases its laws on the soul and religious values, the paradigm referred to in this case is the prophetic paradigm. 


\section{RESEARCH METHOD}

This type of research is descriptive analytical qualitative research, that is legal research where knowledge or theory about the object already exists and wants to provide an overview of the object of research. While the approach used is a conceptual approach. Conceptual approach is a type of approach in legal research that provides an analytical point of view of problem solving in legal research seen from the aspects of the legal concepts that lie behind it, or even can be seen from the values contained in the norm of a regulation in relation to the concepts used. While the data collection technique comes from the literature or this research is also called library research.

\section{DISCUSSION}

1. The Notion of Legal Paradigm

a. The Notion of Paradigm

Before the term paradigm became a popular concept, socio-cultural scientists have used several concepts that have the same meaning as paradigm, namely: theoretical framework, conceptual framework, frame of thinking, theoretical orientation, point of view (perspective), or approach (Syamsudin et al., 2013). Others say that paradigm is understood the same as a world view, a general perspective, or a way of breaking down the complexity (Nurkhalis, 2012).

Thomas Khun is one of the scientists who introduced the term paradigm in his work entitled The Structure of Scientific Revolution, and he is even known as the father of paradigm (Ariefyanto, 2012). He argues that science can develop through a scientific revolution, while the scientific revolution occurs through a paradigm shift. With this thought, Khun wanted to emphasize that scientific change could not occur because of empirical efforts through the process of falsifying a theory, but rather through a very basic change called the scientific revolution. At the same time, this thought is a critique of Popper's though that scientific development begins with the submission of a hypothesis which is then followed by efforts to prove the wrong hypothesis. So when a theory has been proven wrong, it automatically invalidates the previous theory. But if you do not find any more errors in the hypothesis, then the hypothesis turns into a thesis 
(theory) which is accepted as a truth, but is tentative (Ulya \& Abid, 2015).

It is just that Thomas Khun in the context of this paradigm, he does not explain specifically and in detail about what is meant by a paradigm, and does not use the concept consistently in his writings. Perhaps this happened because of an indirect result of the topic of discussion, namely the change of paradigm in the natural sciences, Khun did not described the socio-cultural sciences, perhaps he did not feel the need to distinguish between these two types of science because they are both sciences. Another reason may be that Khun considers the sociocultural sciences not yet a science, because from a certain perspective the status of science has not been successfully achieved by that branch of science (Syamsudin et al., 2013).

Ahimsa Putra tries to detail at least 2 weaknesses of the paradigm concept proposed by Thomas Khun: (Wardiono, 2020, p. 36-37)

1. Referring to Masterman's opinion, that Khun uses the term paradigm with more or less 21 meanings, in this case Khun is inconsistent.

2. As Shapere pointed out, Khun deliberately inflated the meaning of the paradigm to make his views convincing, even though it made the concept even more unclear, even more difficult to understand some important aspects of science itself.

To make it easier to understand this paradigm term, Heddy Shri Ahimsa Putra tries to explain it, according to him Paradigm is a set of concepts that relate to each other logically to form a framework of thought that functions to understand, interpret and explain the reality and/or problems encountered. The word set, it means that the paradigm has a number of elements (not just one element) namely concepts/a collection of certain meanings/a collection of notions that become a unified and logically related (paradigmatic, syntagmagtik, metonymic, and metaphorical), so that it known as set of concepts. Because the concept exists in mind, the collection of concepts that make up the framework is called a frame of mind. While the words that function, the framework of thought certainly has a purpose, so that the frame of mind has a function, namely to understand reality. The reality faced by humans causes reactions in their minds, including questions and feelings of dissatisfaction, because the reality that is being 
faced cannot be answered by the existing frame of mind or is not as expected.

Heddy Shri Ahimsa, the main elements contained in the paradigm are as follows: a) basic assumptions, b) values, c) models, d) problems studied, e) concepts, f) methods research, g) Method of analysis, h) Results of analysis/representation theory (ethnography). The first three elements (basic assumptions, values, and models) are the epistemological basis of a paradigm, while the other six elements are the implications of its epistemological basis.

2. Paradigm of Law

Referring to Thomas Khun's opinion as previously explained that Science will experience a change or shift, so also with law, he also experiences a paradigm shift or paradigm shift. According to Soetandyo Wognjoseobroto, there are at least 3 major paradigms that influence the development of legal science, namely the moral paradigm (the ideal law), the rational paradigm (the rational law), and the scientific paradigm (emperical law).

According to the moral paradigm, the ideal law necessitates the realization of a universal order, manifest in the form of perfect, beautiful, and beautiful harmony and reflecting the final will of God (revelation), having the moral substance of God and having a normative character that is all teaching and obligatory. This is the law that is in the realm of Sollen: das Sollen Welt, and this is law as what ought to be. The moral legal paradigm refers to Aristotle's thought (the teleological-finalistic paradigm). It is just that then this paradigm of moral law, along with the times, experienced a shift in meaning, from what was originally a moral substance of God, with a substantive-moral character (morals) to a new law that was descriptive in nature to control outward behavior, and finally transformed into a law that contained conscience. resides naturally in the heart of every creature born as a human. This rational paradigm refers a lot to the Galilean paradigm (the causal-mechanistic paradigm).

3. Prophetic/Transcendental Law

Prophetic can be defined as an entity that seeks to prepare and provide itself to be able to read and capture the messages of God, and take lessons from them, to then try to implement these messages of God in everyday life, so that it will provide good for himself, society, and nature throughout the universe. (ibid) 
In Islamic literature, especially in the study of Islamic aqidah, prophetic which is then translated by the term Prophet (Nabi), the meaning is distinguished from the prophet. Nabi comes from the word Naba' which means: (Al-Asyqar, n.d., p. 23-24)

a. Allah's news, as contained in the word of Allah SWT:

Meaning: About the great news (naba')

b. Giving news and being given news, says Allah SWT QS Al Hijr: 49, Q.s Al An'am: 2

Meaning: Tell My servants that I am the Most Forgiving, Most Merciful (QS Al-Hijr verse 49)

c. Nabwah which means high Earth, which means that the Prophet has a high dignity and position in this world and in the hereafter. The Arabs use the word Nabi for signs on the earth that are used to find traces. This means that the Prophet is a sign used by humans to seek guidance so that the world and their hereafter become good.

In his book al Mufradāt fì Gharīb al-Qur'ān Imam al Raghib al-Asfahani tries to explain that the meaning of the news stored (contained) in the word prophet is not ordinary news, but news that cannot be wrong. More or less the word nabi is repeated 75 times in 20 letters, while the word naba' is repeated 29 times in 21 letters (Zulaiha, 2017).

The word Rasul comes from the word Irsal which means directing, the Rasul is also defined as someone who monitors the news of the person he sends (Al-Asyqar, n.d., p. 24-25). Some opinions say that there is no difference between a prophet and a messenger, the most famous opinion among the ulema is Prophet is more general than the messenger, the messenger is the person who was given revelation and ordered to convey it. A prophet is a person who is given revelation but is not commanded to convey it. The first opinion and the second opinion are wrong based on a number of arguments: (ibid, p. 25-27)

a. The first error of opinion contradicts the words of Allah SWT Q.S. Al Hajj: 52, which means: And We did not send before you any messenger or prophet except that when he spoke (or recited), Satan threw inti it (some misunderstanding). But Allah abolishes that which Satan throws in; then 
Allah makes precise His verses. And Allah is Knowing and Wise.

b. The second opinion is also wrong because many words of Allah SWT and hadiths talk about the nature of the Prophets and Messengers are the same in terms of conveying revelation to humans. The Messenger of Allah said: "It has been shown to me the moslem people where I saw a prophet with many followers, a prophet followed by one or two people and a prophet with no followers."

The right understanding, the Messenger is a person who was given a revelation by Allah SWT with a new shari'ah, while the Prophet is a person who was sent by Allah SWT to strengthen the previous shari'ah (ibid). From this understanding it is clear that the difference between the Prophet and the Messenger lies in the shari'ah, if the Messenger brings a new shari'ah, while the Prophet continues the shari'ah (not bringing a new shari'ah) brought by the previous messengers, while in terms of the tasks and missions the Prophet and Messenger were sent are same.

Ibn Qayyim said that the importance of the Prophets and Messengers sent by Allah SWT to mankind in living and managing their lives in various fields of economic, social, political, cultural, and legal, he further said:

"Humans really need to know the messengers and the message they brought, believe their words, obey their commands, because there is no way to happiness and luck in this world and the hereafter except through the messengers. There is no way of knowing good and bad in detail except from them. All good deeds and words and morals are nothing but their instructions and teachings. They are benchmarks. Morals and actions are weighed on the basis of their words, actions and characters. By following them, people get different directions from misguided people. The need for them is greater than the need for the body for the spirit, the need for the eye for light, the need for the spirit for life, any need and need is nothing more than the human need for the messengers." (ibid, p. 52)

The tasks carried out by the Prophets and Messengers of Allah when sent on this earth are: (Ibid, p. 65-83)

a. Delivering da'wah (Al maidah: 67)

b. Preaching the teachings of Allah (An Nahl: 36)

c. Give glad news and warnings (Al-Kahf: 56) 
d. Repair and purify the soul, (Al Jum'ah: 2)

e. Straighten deviant thoughts and misguided aqidah, (Al Baqoroh: 213)

f. Uphold the argument, (An Nisa: 165)

g. Leading the Ummah, (Shad: 26 and Al Maidah: 44)

The notion prophetic is sometimes alternately used with the word transcendental in several opinions and writings that contain ethics, morals, and divinity (revelation), as Kuntowijoyo interprets transcendental by basing faith in Allah (Ali Imron: 110) by introducing prophetic science, in the form of humanization. Ta'muruna bil ma'ruf), liberation (tanhauna anil munkar) and transcendence (tu'minuna billah) (Absori, n.d.). Likewise, Satjipto Rahardjo said that with the spiritual intelligence approach, the most perfect intelligence (ultime intelligence) will be obtained, carried out by crossing the lines of formalism (existing rule) and transcendentalism, so that new thoughts can be obtained that are closer to the real truth (the ultimate truth) (Rahardjo, 2000, p. 11). Philip Calyton says that we are now beginning to see a renaissance, a metaphysical (transcendental) revival, of systematic reflection on the nature and creativity of God. Positivists may say that metaphysics (transcendental) is dead, however, it seems that now it is logical positivism that died first. It is interesting that atheistic thinkers from Muslims, Jews and Christians are now again engaged in a very broad exploration of the idea of the "God hypothesis". (Kesuma, n.d., p. 545)

Roger Garaudy gives meaning to Transcendental in three forms of views, namely: a) recognition of human dependence on the creator, b) acknowledgment of the continuity and togetherness between God and man, c) recognizing the superiority of absolute norms that transcend human reason. (Badwan \& Farkhani, n.d., p. 11)

Transcendental thought attracts the attention of the initiators of science, is considered as an alternative future thought in the midst of a positivistic dialectic of rationalist understanding which is considered unable to overcome various problems of life and life. Transcendental thought is related to understanding that places science in a wider reach beyond the normative limits of rational scientific rules. Scientists place transcendental studies in the frame of knowledge that is metaphysical or supernatural because it transcends the boundaries of the physical 
realm and is spiritual in nature. (Basri, 2017)

In Qur'an, spiritual knowledge coincides closely with the truth of reason and human consciousness. So the higher a person's religious awareness, the higher the quality of reason and the spirit of humanity. Not the other way around. By making Allah as the center of orientation, humans will always have the motivation of life, avoiding the pitfalls of being hostile to nature. Because surely humans will be in a losing position. Precisely by making Allah as the ultimate goal he will be free from the suffering of psychological alienation. Allah becomes the All-Present charm that bestows power, control and peace of mind, so that the person concerned is always in God's environment with brilliant intelligence, not in an obscure earth orbit. (Elviandri, 2016)

The Transcendental Dimension was created on several consciousnesses, namely: first, awareness of change, second, collective consciousness, third, historical awareness, fourth, awareness of social facts, fifth, awareness of the existence of an abstract society, and sixth, awareness of objectivity. (Kuntowijoyo, 2017)

According to Kelik Wardiono, the keywords that can be used as a guide to understand the prophetic paradigm in legal science are, first, norms in the normative world are relatively dialectical with the world of ideas and the empirical world simultaneously, as keywords to understand aspects of ontology, second, the integration of science and religion (domestication extension movement process) as a key word to understand the epistemological aspect, third, justice, as a key word in understanding axiological aspects. (Wardiono, 2020, p. 205)

4. The Paradigm of Prophetic Law from the Perspective of Arkanul Bai'ah Imam Hasan Al Bana said: O my sincere brothers, there are ten pillars of our allegiance, so take care of them, namely: al fahm (understanding), al ikhlas (sincerity), al 'amal (aactivity), al jihad (holy war), at tadhhiyah (sacrifice), ath tha'ah (obedience), ats tsabat (constancy), at tajarrud (dedication and totality), al ukhuwwah (Brotherhood), dan ats tsiqah (belief). (Al-Hilali \& Mahmud, n.d.)

Arkanul Bai'ah consists of 2 words, namely rukun and bai'ah. First, the part of something if it left out, the activity becomes useless or cannot be upright. Second, the most powerful part or the big thing. Third, something used to 
strengthen. While bai'ah means to promise to pour out obedience with a compensation. The person who takes allegiance is the person who promises to give obedience even though obedience requires wealth, energy, or soul as long as it is in order to get the pleasure of Allah SWT. (ibid)

Of the 10 (ten) arkanul bai'ah stated above, in creating the paradigm of prophetic law in this paper, the focus will be on the first pillar of bai'ah, namely al fahmu which is the core and foundation of the other pillars. From the pillars of al fahmu, people are required to understand Islam with a true and sincere understanding as the understanding of salafus shaleh and ahlu sunnah wal jamaah, so that a person is in the right framework of understanding without making one thing easy and without being extreme with other matters.

Hasan Al Bana said, what is meant by understanding (al fahmu) is fikrah (thoughts and conceptions) is pure Islam and understands Islam within the limits of twenty principles. The 20 (twenty) principles in question are that Islam is a perfect religion, the source of Islamic law and the rules for understanding it, faith, worship, and mujadah, using facilities as long as they are not jahiliah means, the opinion of the imam is the breaker of problems for which there is no text and that distinguishes between worship and habit, balances weighing the opinions of the ulemas, ijtihad, taklid and sects, differences in matters of furu' and ethics in differences, prohibited from complicating oneself in religion, faith in Allah and His attributes, bid'ah, the criteria for loving pious people and their boundaries, the provisions of the pilgrimage to the grave, prayer and tawasul, traditions and customs can be used as a basis as long as they do not change the principles of the shari'ah, faith and actions of the heart, the position of the mind, influence and boundaries of its working area, shari'ah takes precedence over reason, and the limits of disbelief according to Ahlu Haq.

In oral Arabic the meaning of Al-Fikr or Al-Fikrah, first, an idea about something. Sibawayh said; Al-Fikr (idea) dan Al-'Ilm (knowledge) and An-Nazhar (attention) will not become one. Second, a thought about something or contemplation. Third, According to Al-Layth; At-Tafakkur is another name for AtTafkir. Fourth, there are some Arabs who call it Al-Fukraa, but they are not famous. Fifth, Al-Jauhari said that tafakkur means observation. Sixth, also means 
intention or desire. Seventh, Some say it is more fluent if read Fakr or Fakrah than Fikr or Fikrah. So fikrah can be interpreted by understanding Islam in the way that Allah and His Messenger teach how to understand Islam. The word of Allah SWT, which means: O you who have believed, do not put (yourself) before Allah and His Messenger but fear Allah. Indeed, Allah is Hearing and Knowing (Q.s Al Hujurat: 1).

In this paper, an alternative idea of the prophetic paradigm in arkanul bai'ah optics is deliberately proposed because:

a. The paradigm of prophetic law is still possible to be developed by looking at it from several points of view

b. The theory of arkanul bai'ah was initiated by Imam Syahid Hasan Al Bana, a charismatic ulema and recognized for his personality, knowledge, worship, noble character and his contribution to the world has been evident through his ideas, opinions and thoughts. (Qaththan, n.d.)

c. Al Fahmu which is defined by Fikrah is in line with the meaning of prophetic philosophy in seeking and getting closer to the divine truth.

A. Assumptions of the Prophetic Paradigm

1. Ontological Assumption

a. The Nature of Existence

One of the 20 principles of al fahmu in the frame of arkanul baiah, Syahid Hasan Al Bana says that Islam is faith. This means that it is a principle that contains basic items dealing with all phenomena of human life. A moslem must believe in the aqidah, believe in his honesty and truth, and be ready to die in his path and to defend it. (ibid)

The foundation of the Islamic creed is the belief in the existence of Allah, characterizing it by His attributes, naming it by His names, and imitating it as ilah and $r a b b$ (ibid). The existence of Allah or better known as the nature of existence, Imam Shahid Hasan Al Bana said that the attributes of Allah must be believed in without interpreting and not denying them. (Khatib \& Hamid, 2007, p. 163)

Salaf ulemas say: we believe in the verses and hadiths as they are and leave the explanation of their meaning to Allah SWT, we leave the mastery of 
knowledge about them to Allah SWT. Moreover, Rasulullah SAW has forbidden us from that in his saying: think about Allah's creation and do not think about Allah's substance, because you will not be able to reach it.

If we want to think more deeply about Allah's creation starting from ourselves, the sky, the earth and everything in it, we will arrive at that whatever is in the world today cannot stand alone, meaning it does not occur by itself and is separated from each other, it exists because it was created and every creation (that exists) in the world further emphasizes the existence of Allah.

According to Prof. Dr. Umar Sulaiman Al Asyqar conveyed 2 things that emphasized the existence of Allah SWT: first, human nature, the word of the Qur'an emphasizes that the straight nature, and the soul that is not littered by shirk confirms the existence of the Creator without the need for proof, the word Allah SWT in surah Ar Rum: 30. Second, the law of cause and effect (causality) which states that all something cannot happen by itself without something else, because it does not have a sufficient cause for its existence and cannot of itself bring about something because it cannot give to another something that it does not have itself. The word of Allah SWT in surah At Thur: 35-36.

\section{b. Source Existence}

Imam Hasan Al Bana said that the Qur'an and Sunnah are a reference for all moslems in understanding Islamic laws. The Qur'an is understood according to the rules of the Arabic language without any effort and not haphazardly and the understanding of the Sunnah refers to the tsiqah hadith narrators.

Islamic laws are shari'ah laws, namely orders from shari'ah makers that apply as shari'ah, such as requests to do something that must be (mandatory), requests that are not mandatory (sunnah), requests to leave something (haram), requests to leave something that is not necessary (makruh), and shari'ah law is also related to the ability to choose between doing or leaving (mubah). (Al-Hilali \& Mahmud, n.d.)

To understand the shari' ah law, it refers to what was conveyed by Imam Hasan Al Bana above based on the Qur'an and Sunnah. As sunnah, which function is to explain what the Qur'an has preached, to detail its generality, and to interpret parts of the Qur'an that require interpretation. As for Ijma, it is obligatory to rely 
on the Qur' an and Sunnah, not to deviate from them. While qiyas and ijtihad refer to the commitment to the texts of the holy book and as sunnah. In this way, it is clear that the shari'ah laws refer to the Bible and the Sunnah.

Then what about revelation (delivering something to the heart /whispering of angels), al khatir (conscience), kasyf (knowing relations or phenomena that have not been known before), and rukyat (eyesight)? Iman Hasan al Bana said that revelation, al khatir, kasyf, and rukyat are not included in the propositions of shari'ah laws. These are not taken as legal considerations except on one condition that they do not conflict with the laws and religious texts. Even so, there are still groups who recognize that revelation, al khatir, kasyf, and rukyat are legal arguments such as musyabbihah, muktazilah, jahmiah, jabariyah, qadariyah and others. For this reason, the ulemas have criticized him a lot and removed the perpetrators from the frame of faith, even Abu Jakfar ath Thawi said that they are misguided and evil we break away from them and may Allah protect and guide us.

Likewise with traditions and customs which are then better known as ' $U r f$, that traditions and customs can be used as a source of foundation as long as they do not change the principles of the shari'ah. (Al-Wasyli, 2018)

'Urf can be divided into several parts, namely: first, 'Urf in terms of naming then it is divided into 'Urf qauli (speech traditions) and 'Urf amali (deed traditions). Second, in terms of generality and specificity, it is divided into ' $U r f$ 'aam (general habits) and 'Urf khas (special habits) and third, in terms of validity it is divided into 'Urf sahih (true) and 'Urf Batil (damaged).

Regarding 'Urf from the side of its validity, Imam Hasan Al Bana said: A wrong tradition should not change the nature of the terms of the shari'ah, in fact there must be an effort to examine and re-check the limits of the meaning intended by him, such as the habit of people doing evil (usury, drinking liquor, killing, adultery and so on), after being named by another name or carried out in other ways that lead to the nature of the unlawful act in question.

2. Epistemological Assumptions

a. How to understand and develop the object of science

Imam Hasan Al Bana emphasized that in understanding knowledge and 
developing it, it is important to pay attention to the rules and must be in accordance with the spirit of revelation.

Imam Hasan Al Bana stipulates that the reference in understanding the Qur'an is Arabic which has a clear meaning. It should not be understood takalluf (interpreting the verse to go beyond the proper meaning and ta'assuf (happily). This is because the Qur'an as a whole was revealed in Arabic, so to understand it, there is no other way but to use Arabic (Khatib \& Hamid, 2007). This is as contained in the word of Allah SWT, Meaning: Verily, We have sent it down as an Arabic Qur'an, so that you may understand (Q.S. Yusuf: 2).

Among the guidance of the noble companions is to avoid and also prohibit the attitude of forcing oneself in understanding the Qur'an. As for understanding the sunnah, it must be understood through trusted hadith experts, because they are the people who are most able to know the authentic and dha'if hadiths and know the various indications and their meanings..

The limitation of the Qur'an and Sunnah as a reference in understanding various laws meant by Hasan $\mathrm{Al}$ Bana is:

- Strengthening the understanding of Hasan Al Bana as an understanding that takes and is in accordance with the path traversed by the pious salaf.

- As a protector from misguidance.

- Blocking the way for people who are astray and deviant who like to mock the human's mind and deceive the common people with strange understandings, far from the soul of the Qur'an and its goals and with fabricated hadiths and forced interpretations and carried out haphazardly.

- Minimizing self-imposed and careless attitudes in understanding the Qur'an so that it can maintain the integrity of individuals and the community so that people do not get lost and fall apart.

Then what about the position and role of mind? Islam actually frees the mind, recommends doing research on nature, elevating the degree of knowledge and ulemas, also welcomes the presence of all that is good and useful. Wisdom is the property of the believers, wherever it is obtained, he is the person most entitled to it.

Further, how Islam views a mind can be detailed as follows: 
- Mind is the greatest blessing that Allah has given to humans. The word of Allah SWT in surah Al Baqoroh: 170 and Al Qashas: 50.

- Islam commands us to think about nature. Islam not only frees the mind from sharing shackles but also recommends doing research on the universe and calls on it to contemplate and think about various creatures. All of that is to recognize the power of Allah swt. Thus faith will increase and worship of Allah will be more perfect. The Word of Allah SWT in surah: Yunus 101, Ali Imran: 190, and Adz Zariyat: 20-21.

- Islam glorifies knowledge and ulemas. Islam glorifies and elevates the degree of knowledge, namely useful knowledge, which can realize the implementation of the caliphate and prosperity on earth, and become a source of strength, solidity, and goodness for moslems and humanity. The word of Allah SWT in surah Az Zumar: 9, al Mujadilah: 11. The awards given by Islam to science and ulemas include the shari'ah sciences, natural sciences, and other sciences as stated and implied in the Qur'an and Sunnah.

However, Islam gives a high respect for reason with its role and position, still, the shari'ah and a mind have their respective territories and their roles should not collide with each other so that it leads to chaos, confusion and never reaches the destination, because both shari' ah and a mind has a different perspective.

The syar'i view is all things covered in the texts of the Qur' an and Sunnah, in the form of lawful and unlawful laws in all fields (aqidah, morals, worship, muamalat and others). Also about nature, life, various sciences such as medicine, astronomy, agriculture, and so on. The view of a mind is everything that is obtained through research, monitoring, experimentation, study, making conclusions, and analyzing various problems of nature, life, various sciences and religious and other world problems.

The areas of the shari'ah in particular where the mind cannot enter are such as the problem of the unseen (heaven and hell, angels, jinn) and the problem of lawful and unlawful. In this case, the mind has no right to give fatwas or make up, but it is only in charge of understanding and interpreting and taking lessons from it. The area of mind in particular is where the shari'ah does not interfere in these 
fields, such as the affairs of the world, nature and life where research, experimentation and analysis can be carried out, so that it can conclude scientific principles in the fields of chemistry, physics, and biology that can help achieve new discoveries and new creations. As for the areas that are cultivated together with the shari'ah and reason, namely absolute fields that cannot be interpreted and doubted, because they are clear. Examples of faith in Allah (oneness and perfection), faith in the primacy of Allah's shari'ah over all other rules.

b. Truth validity

As for the law, some of them are qath'i (certain) and some are zhanni (based on strong allegations). Qath'i is a law whose sanad is mutawatir, narrated by many people from people who are usually impossible if they agree to lie, matan (the redaction) shows a textual meaning and does not contain other possible meanings (Al-Wasyli, 2018, p. 385). An example of the word of Allah SWT in Surah Al Ikhlas verse 1. Zhanni is a law that has lost one of the characteristics of qath'i law (the text is mutawatir but the meaning has many possibilities). ${ }^{59}$ For example: QS. Al Maidah about wudhu (ablution).

Qath'i is something that must fulfill two things, namely a broad argument that shows its truth and the establishment of another argument that shows the impossibility of the other. As for zhanni is the opinion that is favored, it is expressed in relation to the interpretation of natural phenomena, analysis of social problems, and the like.

Dr. Abdul Karim Uthman said: many people ask about the relation between mind and revelation, some people place mind too high and lower revelation, others place revelation too high and marginalize the role of mind, these two views are not in line with the Islamic perspective.

So it would be a big mistake to make human mind the opposite of revelation, because mind is one of the human devices that it uses to receive revelation, it is able to understand things that can be understood and give up things that are beyond its capabilities. Therefore Sayid Qutub said: mind and everything that exists in humans is not perfect and absolute, it is limited by time and place, at certain times some of them must accept absolute essences, such as divinity and how the relationship between the divine will and the creation of creatures. What 
mind does is nothing but accept these absolute global things for which there is no way of knowing.

Revelation is broader and more comprehensive. It is the source of knowledge to which reason refers. It is a balance that the mind uses in deciding various things, especially matters relating to the essence of life and this realm of existence. Then Imam Hasan Al Bana said: if the syar'i view and the mind view work in accordance with their respective fields then the two will never disagree about qath'i matters. (ibid)

True religion and mind never contradict, the difference occurs when there is something spiritual in the shari'ah and something spiritual in science, or in other words, between syar'i theory and scientific theory, related to this Imam Hasan Al Bana said: zhanni things from both need to be interpreted to be in line with the qath' $i$, but if both are spiritual then the syar' $i$ view is more appropriate and must be followed until something rational is proven true or collapses by itself.

\section{Axiological Assumptions}

a. Source of Value in determining the benefits of science for humans

Thus, in the development of legal science and the determination of legal substance inspired by the prophetic spirit (transcendence) it must refer to the Qur'an and Sunnah and pay attention to tsawabit (qath'i) and mutaghayirat (zhanni) aspects.

The Qur'an and the Sunnah must be understood in accordance with the provisions and established rules, while the mind in working to understand revelation and reality must be guided by the Qur' an and Sunnah, so that shari'ah goes according to its views and mind works according to its territory.

b. The benefits of science for humans

Islam is here to realize the benefit of mankind and keep away various kinds of damage, both in matters of religion and the world. Therefore, the principle and basis of shari'ah law is that Islam is the benefit of servants in the life of this world and the life of the hereafter. It is a shari'ah whose whole is justice, mercy, benefit and wisdom. (Khatib \& Hamid, 2007, p. 251-252)

Therefore, everything that comes from the spirit of justice to injustice, from mercy to vice versa, from benefit to damage, and from wisdom to futility is 
not from Islamic law, even though it is forced in various ways or by takwil.

This great rule will lead to progress while maintaining the authenticity of religion, in fact moslems are more entitled to master all goodness in any field (medicine, astronomy, management, construction, industry, agriculture and so on, so that it is in line with what the Prophet SAW said, Meaning: Wisdom is the lost property of the believer wherever it is found, he is the one who is most entitled to it (Hr. At Tirmidzi).

B. The Prophetic Paradigm Model of Legal Science

In the ontological aspect, the object of legal science is the norm, the norms contained in the shari'ah are Qath'i/tsawabit and the Zhanni (mutaghayirat) norms. In this case the intended norm is a zhanni/mutaghayirat or relative norm that requires and opens the role of reason to develop, explore, and explore the meaning contained in the norm while still being guided by the spirit of revelation.

The transcendental aspect in this prophetic paradigm of legal science lies in the use of revelation (Qur'an and Sunnah) as the only source of reference (benchmark), meaning that everything must be measured by revelation. Thus the position of revelation plays an important role as a source in formulating norms, interpreting norms, enforcing norms and at the same time as a basis for carrying out legal transformation.

In the epistemological aspect, there is no separation between revelation and science, both of which are inseparable from each other. Revelation (Qur'an and Sunnah) must be understood in accordance with its rules, should not be understood in takalluf and taasuf. If there is a conflict between shari'ah theory and scientific theory in zhanni (relative) matters, then an interpretation must be made between the two, and even if you have to choose between the two, the shari'ah must take precedence.

In the axiological aspect, the importance of emphasizing the tsawabit and mutaghayirat aspects, so that the syar'i view works according to its scope, and the mind's view works according to the designation of its working area. So that there is great benefit (justice, mercy, and wisdom) for mankind and farthest from all forms of damage (tyranny, enmity, and futility). 


\section{REFERENCES}

Al-Wasyli, A. B. Q. (2018). Syarah Ushul 'Isyrin (menyelami samudra 20 prinsip hasan al bana). Solo: Era Adicitra Intermedia.

Wardiono, K. (2020). Ilmu Hukum Profetik: Hampiran Basis Epistemologi Paradigmatik. Surakarta: Muhammadiyah University Press.

Kuntowijoyo. (2017). Transendensi Hukum Prospek dan Implementasi. Yogyakarta: Genta Publishing.

Syamsudin, M., Koesnoe, M., Putra, H. S. A., Abdullah, M. A., Thontowi, J., \& Sutiyoso, B. (2013). Ilmu Hukum Profetik: Gagasan Awal, Landasan Kefilsafatan, Dan Kemungkinan Pengembangannya Di Era Postmodern. Yogyakarta: PSH FH UII.

Al-Hilali, M., \& Mahmud, A. A. H. (n.d.). Syarah Arkanul Baiah. Solo: PT Era Adicitra Intermedia.

Khatib, M. A., \& Hamid, M. A. H. (2007). Risalah Ta'alim. Jakarta: Al I’tishom.

Al-Asyqar, U. S. (n.d.). Rasul dan Risalah. Riyadh: IIPH.

Al-Asyqar, U. S. (2018). Pengantar Studi Aqidah. Jakarta: Pustaka Al Kautsar.

Sudiyana, S., \& Suswoto, S. (2018). Kajian Kritis Terhadap Teori Positivisme Hukum dalam Mencari Keadilan Substantif. Jurnal Ilmiah Ilmu Hukum QISTIE, 11(1). https://doi.org/10.31942/jqi.v11i1.2225

Nurkhalis. (2012). Konstruksi Teori Paradigma Thomas S. Kuhn. Jurnal Ilmiah Islam Futura, 11(02), 79. https://doi.org/10.22373/jiif.v11i02.55

Ulya, I., \& Abid, N. (2015). Pemikiran Thomas Kuhn Dan Relevansinya Terhadap Keilmuan Islam. Fikrah: Jurnal Ilmu Aqidah Dan Studi Keagamaan, 3(2), 249276.

Zulaiha, E. (2017). Fenomena Nabi dan Kenabian dalam Perspektif AlQuran. Al-Bayan: Jurnal Studi Ilmu Al- Qur'an Dan Tafsir, 1(2), 149-164. https://doi.org/10.15575/al-bayan.v1i2.1599

Kesuma, D. A. (n.d.). Penegakan Hukum Berbasis Transendental.

Rahardjo, S. (2000). Mengajarkan Keteraturan Menemukan Ketidakteraturan. Semarang: Pidato Mengakhiri Jabatan Guru Besar di Universitas Diponegoro.

Badwan, \& Farkhani. (n.d.). Hukum Transendental: Argumentasi Hukum menggunakan norma Agama di Pengadilan Negeri Purwerejo.

Basri, B. (2017). Penegakan Hukum Kejahatan Korupsi Melalui Pendekatan Transendental. Varia Justicia, 13(2), 82-92. https://doi.org/10.31603/variajusticia.v13i2.1882

Elviandri. (2016). Hukum Transendental Dalam Konstelasi Pemikiran Hukum Postivistik Di Indonesia. Yustisia Merdeka: Jurnal Ilmiah Hukum, 2(1).

Ariefyanto, M. I. (2012). Thomas Kuhn, Bapaknya Paradigma. Retrieved from website: https://www.republika.co.id/berita/m1nbia/thomas-kuhn-bapaknya-paradigma

Rahimahullah, S. M. K. al Q. (n.d.). Gerakan Islam terbesar yang membangkitkan kesadaran Islam di Dunia Islam. In Pakar Tafsir dan Hadits. 